\title{
FROM GREEN PROMISES TO POLITICS AS USUAL: THE CONSERVATIVE PARTY, THE COALITION AND THE ENVIRONMENT, 2005-2013*
}

\section{James CONNELLY**}

\begin{abstract}
This paper examines the trajectory of attitudes and policy commitments on the environment within the British Conservative prior to and following the Conservative/Liberal Democrat coalition formed after the election held in May 2010. The first part addresses the environmental policy of the British Conservative Party under the leadership of David Cameron from 2005 to the general election in 2010. The second examines how Cameron's environmental commitments were translated into practice following the formation of the Conservative/Liberal Democrat Coalition in May 2010. The third part characterises and employs the idea of 'politics as usual' to describe the forces directed against strong environmental policies and draws together the themes of the first two parts through a consideration of the Coalition's attitude to airport expansion in the UK.
\end{abstract}

Keywords: Environment, Conservative Party, Liberal Democrat Party, United Kingdom

$\ddot{O} z$

Bu çalışma İngiliz Muhafazakâr partisi içerisindeki gidişatın durumunu ve çevre konusundaki taaddütlerini, Mayıs 2010 seçimlerinden sonra kurulan Muhafazakâr/Demokrat koalisyonu öncesindeki ve sonraki dönemde incelemektedir. Çalışmanın ilk bölümü David Cameron liderliğindeki Ingiliz Muhafazakâr Partisi'nin çevre politikalarını 2005 döneminden 2010 genel seçimlerine kadar olan dönem içerisinde ele almaktadır. İkinci bölüm Cameron'ın

\footnotetext{
${ }^{*}$ A more detailed account of these topics can be found in Connelly 2009, 2011 and 2013.

** Prof. Dr., University of Hull, School of Politics, Department of Philosophy and International Studies, e-mail: j.connelly@hull.ac.uk
} 
çevresel taaddütlerinin Mayls 2010'da kurulan Muhafazakâr/Liberal Demokrat koalisyonunun sonrasında nasıl pratiğe dönüşürrdügünü incelemektedir. Üçüncü kısım birinci ve ikinci kısımda anlatılanları birleştirerek koalisyonun İngiltere'deki havaalanlarının genişlemesine karşı olan tutumunu 'olağan politika' kavramı üzerinden göstermektedir.

Anahtar Kelimeler: Çevre, Muhafazakâr Parti, Liberal Demokrat Parti, Birleşik Krallık

\section{Introduction: David Cameron, the Conservative Party and the Environment}

This paper examines the trajectory of attitudes and policy commitments towards the environment within the British Conservative prior to, and subsequent to, the Conservative/Liberal Democrat coalition formed after the election of May 2010. Following a consideration of the environmental policy of the Conservative Party under the overtly radical and 'green' leadership of David Cameron from 2005 to the general election in 2010, it examines how Cameron's environmental commitments were translated into practice in government. It concludes with a characterisation of 'politics as usual' which is then employed to analyse the forces directed against strong environmental policies and finally draws together its leading themes through a consideration of the Coalition's attitude to airport expansion in the UK. The paper is an internal reading of Conservative and Coalition environmental politics and policy, exploring its policy, personal and power dynamics. Although, clearly, UK environmental policy is constrained and to some extent moulded by external policy sources, most notably the European Union, space precludes an examination of this.

A notable feature of David Cameron's becoming leader of the Conservative Party in 2005 was the prominence he gave to the environment. None of Cameron's predecessors had been so environmentally committed as he did, and his leadership on the issue even led to arguments over which party was more green (Schlosberg \& Rinfret, 2008: 257). Cameron certainly established his green credentials early:

On the very day that Mr Blair publicly doubted the value of a new climate change treaty, Mr Cameron put forward ... the most radical measures to tackle global warming ever proposed by a leading British politician. Then [2005] he was still a leadership candidate. When he won, he focused on the issue both in his acceptance speech and in his first Prime Minister's Questions, and ... recruited the radical environmentalist Zac Goldsmith to help lead a review of Conservative policies. At the same time he appointed Peter Ainsworth, probably the most respected green politician in parliament, as his Environment spokesperson. (Independent on Sunday, 2006) 
Cameron had made a good case to be taken seriously as an environmentally committed leader. Although at this stage this environmentalism could be seen as making easy promises, it nonetheless had measurable effects while they were still in opposition. For example, through pressure on the government, in calling for the setting of a target for cutting Britain's carbon emissions by 2050, they prompted the introduction of the Climate Change Act (2008) which requires the UK to cut its greenhouse gas emissions by 80 per cent (based on 1990 levels) by 2050. This implied that future governments will have to meet difficult targets whether or not the economy is in recession. The Energy Bill (2008) made provision for the introduction of a feed-in tariff for renewable electricity and renewable heat incentives. This was inserted into the bill as a result of an amendment tabled by the Conservative and Liberal Democrat parties. By leading, promoting and publicising the green agenda, and by outflanking the government on the environment, Cameron caused the legislation to be more radical than it otherwise would have been.

But this was all in opposition and left untouched the question of how resilient or robust the Conservative Party's environmental commitment would be if they formed a government. In 2008 Cameron claimed that his green shoots would not wither in the frost of economic hard times: but given the depths of the looming recession, was this convincing? In comparable circumstances in the mid-1990s the environment moved rapidly down the policy agenda. Further, it was noted that in a statement made at the same time about his priorities for government, Cameron failed to mention the environment or climate change (Grice, 2008).

\section{Conservatism, the party and the environment}

The Conservative Party under Cameron was highly successful in appealing to the green movement. Further, many environmental pressure groups, think tanks and activists were favourably impressed not only by Mr Cameron himself, but also by his choice of Peter Ainsworth as shadow Environment Secretary. Ainsworth was widely regarded as being genuinely engaged with green issues: his credentials were impeccable and he lent credibility, commitment and policy weight to Cameron's rhetoric which otherwise might have been more vulnerable to the charge of political opportunism. Indeed, Ainsworth was at the centre of the Conservatives' outflanking of the Labour government in the introduction of the Climate Change Act. There was also a depth in policy advice. The Quality of Life group, led by John Gummer (now Lord Deben) and Zac Goldsmith (now a Conservative MP) produced some important and radical policy documents, which were taken seriously by the leadership of the party. But other doubts remained. One concerned the environmental commitment of other shadow ministers: many believed that the shadow Chancellor, George Osborne, or Kenneth Clark (shadow Business Secretary) and others, would do all they could to lower environmental 
expectations and prioritise conventional notions of economic growth. A related concern was whether the party's environmental aims, no matter how genuine, could be carried out in the relatively painless way (through ecological modernisation) Cameron was committed to. Cameron's commitment to ecological modernisation was evident in one of his early speeches as leader in which he first claimed that the Conservatives and the environment had a natural affinity and that the Conservative Party had a 'proud green heritage' and went on to argue that it was false to regard the environment and economic growth as necessarily opposed. Green growth would mean 'harnessing existing and developing technologies in energy and transport', 'putting a price on carbon emissions and ensuring that the polluter pays; and 'enabling the market to do what it has always done: find the most efficient and cost-effective way of doing business' (Cameron, 2006).

Many concerns of environmentalists overlap with those of traditional conservatism: for example, tradition, continuity, stability, organic change, prudence, and appeals to community. It can be argued that there is a deep affinity between ecological theory and conservative philosophy, in that both share a multigeneration perspective, give primacy to the common life, see danger in novelty and give a central place to the virtue of prudence. There is scepticism about the possibility, inevitability or desirability of 'progress' and an emphasis on continuity and change as occurring within a developing tradition rather than in the light of a 'rational' blueprint for society (Gray, 1993).

The difficulty here is that ultimately the claim of a link between the Conservative Party and environmentalism rests on an ambiguity between conservatism qua disposition and conservatism qua what the Conservative Party stood for. But the link between conservation, conservatism and Conservative is not a necessary one and therefore the claim that the Conservative Party is committed to environmentalism through its name and history is misleading. Further, it is not at all clear that the Conservative Party itself will ever accept the full implications of stringent environmental policies, which tend to point towards government intervention, regulation, and increased taxation. Attitudes within the Conservative Party range from climate scepticism and an associated orientation towards economic growth which accepts that there is a trade-off between economic growth and the environment and chooses the side of economic growth, to those who adopt a form of ecological modernisation responding to environmental problems largely through traditional means and market based solutions. More radical green voices, such as Goldsmith's, are clear outliers.

\subsection{Environmental Policies, Ecological Modernisation and Challenges}

From where was the Conservatives' current environmental thinking derived in the early years of Cameron's leadership? John Gummer was Chair of the Quality 
of Life Policy Group, set up by Cameron in 2005; the Vice-Chair was Zac Goldsmith. Its remit was to recommend policies to the Shadow Cabinet; in 2007 they produced Blueprint for a Green Economy which asserted that 'Business as usual is not a sustainable option ... Capitalism is evolving around the world, and we believe that the critical next stage is to ensure that it 'tells the ecological truth'. It is in the interest of both rich and poor that we create a model of growth that can be sustained' (Quality of Life Policy Group, 2007: 3). Its recommendations included higher taxes on short-haul flights and fuel inefficient cars; a power station waste heat levy; a moratorium on airport expansions; and curbs on energy-wasting household goods; feed-in tariffs for small-scale low carbon technologies; restrictions on energy-wasting stand-by lights; and a cap on energy use by domestic appliances. The policy paper Power to the People was published in the same year and its themes were endorsed by the policy paper The Low Carbon Economy: Security, Stability and Green Growth (2009), published at the precise moment the Labour government announced plans to support the building of a third runway and a sixth terminal at Heathrow. This enabled the Conservative Party to claim the environmental high ground by re-asserting its opposition to expansion. The paper stated that the low carbon economy would 'strengthen our economy. Decarbonising Britain will help create hundreds of thousands of jobs ... and improve Britain's competitiveness ... A decarbonised Britain will be a world leader in green technology, engineering, innovation and growth' (Conservative Party, 2009: 3). It included proposals to: transform electricity networks with 'smart grid' and 'smart meter' technology; create a 'decentralised energy revolution' through 'feed in tariffs' for electricity generation to multiply electricity production from micro-generation; expand offshore wind and marine power by incentivising the National Grid to construct a network of under-sea cables; and introduce incentives for electricity network operators to establish a national recharging network, leading to the development of electric and plug-in hybrid vehicles (4-5). In 2009, Peter Ainsworth introduced the Green Energy Bill in the House of Commons: this was a private member's bill, whose purpose was to take further the Climate Change and Energy acts of 2008, and it illustrated his personal commitment to environmental action. It sought 'to trigger government action that will pay people for the energy they produce' and to remove bureaucratic blockages in the planning system 'to make it easier for people to install technologies in their homes, businesses and farms that create or save energy' (Ainsworth, 2009). These moves indicated that at least some parts of the Conservative Party were determined to push the Labour government on climate change and energy. However, we need to consider the extent to which this approach would be, in the longer term, stable, sustainable and sufficient. 


\subsection{Challenges and difficulties}

The environment as a policy issue sits on top of some of the key fault lines in Conservative Party policy and doctrine. Thus, there has been willingness to use markets and create commercial frameworks giving businesses confidence to invest in innovation; but green taxes were regarded less favourably and only to be considered if they changed behaviour and replaced old taxes rather than added to them. This raised the question of whether a Conservative government would prioritise environmental ends by adopting non-market, regulatory solutions, or limit its environmental policy responses to what could be done within the constraints of market-based solutions. Although Cameron himself had a track record of environmental commitment, there are other dimensions to the Party's political thinking which constrained the radicalism of any solutions it was prepared to accept. For example, Policy Exchange is an important and influential Conservative think tank, which takes a strongly business and market orientated approach, and is supported by George Osborne among others (Beckett, 2008). At various times it has suggested that business should run parts of the welfare state and that planning laws should be radically relaxed in favour of developers. It has suggested 'a doubling in size of the current motorway network' and the lowering of fuel and road taxes. These policies are rather more mainstream within the Party than Cameron's. The point, however, is that their policy solutions are, as a matter of principle, free market solutions. In so far as the Cameron-led Conservative Party adopted the same view there were bound to be severe constraints on any environmental policy it would be able to implement.

An example of the way in which environmental commitments could be construed as opportunistic was provided by the discussion over airport expansion. The Conservative party declared early that they opposed the third runway at Heathrow and re-affirmed their opposition when the Labour government came out in its favour. But, it is easier to oppose a third runway than to make cheap flights more expensive and Theresa Villiers (then shadow Transport Secretary) did not 'rule out airport expansion in the south-east' (Stratton, 2009). The policy could be construed as politically opportunistic, based less on serious environmental considerations (climate change), than on narrower more local concerns (noise pollution). Again, as part of her statement on Heathrow, Villiers announced plans for the next phase of high speed rail (HS2), described as a 'momentous step forward for Britain's transport infrastructure.' The proposal is for a high speed rail line between London and the north. Villiers claimed that it would benefit businesses, heal long-standing divisions in the economy by shrinking the distance between north and south, relieve over-crowding on existing lines and help protect future generations from climate change (Summers, 2008). These are worthy aspirations: but there are inconsistencies at the heart of the Conservatives' 
thinking. For example, a true high speed rail link is hugely expensive on fuel consumption and associated GHG emissions: competing with air travel generates comparable environmental damage. Further, most environmental groups oppose it, arguing for upgrading the existing system, and the arguments in its favour are typically not environmental, but economic (FOE, 2010).

\subsection{From Opposition to Government}

The easiest way for a mainstream politician to argue that strong green policy will not be damaging to their party and the interests of its supporters is to employ the notion of ecological modernisation. But, even supposing that this is a viable solution, it might still appear too new and speculative to appeal to the party faithful and its business backers. A related question was whether the commitment to environmentalism could survive the credit crunch and economic recession. It is easier to press environmental claims when the economy is buoyant than when in recession. Given this, how far could one trust Cameron's reassurance in a speech in 2008 that the party's environmentalism would not be dropped in hard times? In the speech he denied that environmentalism was a fair weather policy and that when 'the economic going gets tough, the green agenda has to be dropped'. On this view, 'protecting the environment is a luxury rather than a necessity - and it's a luxury we just can't afford in an economic downturn.' He stated that he wanted this generation to be the one which found a way 'to combine economic, social and environmental progress' and concluded by arguing that 'it's not that we can't afford to go green - it's that we can't afford not to go green' (Cameron, 2008). However, with the intensification of worries about recession and the economic downturn, Cameron had already begun to downplay his concern with the environment by the end of 2008: 'Cameron - having established his reputation with the 'Vote Blue, Go Green' pledge - seemed scarcely to mention climate change any more (Lynas, 2008). ${ }^{1}$

Thus, leading up to the general election in May 2010, the Conservative Party seemed to have a genuine environmental commitment but there was doubt as to its depth and tenacity. An incoming Conservative government, whatever its rhetoric, would centre its environmental policy on a weak interpretation of sustainable development and ecological modernisation, in which its policy-making would be largely limited to market-based approaches.

\section{And then came the Coalition}

Three days after the formation of the Conservative/Liberal Democrat coalition government in May 2010, David Cameron pledged that 'This will be the greenest government ever'. It seemed that the famous slogan 'Vote Blue, Go Green', which

\footnotetext{
${ }^{1}$ It is interesting to note that Cameron's speech is no longer available on the Conservative Party website.
} 
defined the Conservative Party's approach in the two or three years leading up to the general election of May 2010, was alive and well. However, we are no longer dealing with the Conservative Party alone, but with the complexities of a coalition.

In their joint programme the Coalition made the declaration that 'the days of big government are over; that centralisation and top-down control have proved a failure' (HM Government, 2010: 7). They then stated boldly the potential for convention-challenging, radical reform in building a new economy 'from the rubble of the old,' and to this end they would 'support sustainable growth and enterprise ... and promote the green industries that are so essential for our future (HM Government, 2010:7). They added that they would avoid governmental interference, and change behaviour not through rules and regulations, but in a 'smarter' fashion, 'finding intelligent ways to encourage, support and enable people to make better choices for themselves' (HM Government, 2010: 7-8). What did this add up to in practice?

In their manifestoes the Conservatives claimed that 'environmental issues must be at the heart of politics', while the Liberal Democrats claimed that all of their policies 'have a green thread running through them'. They agreed on the need for a low-carbon economy, and a key commitment in the Conservative manifesto was to establish a Green Investment Bank. The Conservatives wanted 15 per cent of UK energy to come from renewable sources by 2020 , while the Liberal Democrats wanted 40 per cent of electricity to come from renewable sources. They agreed on the need for new rules to limit emissions from fossil fuel power stations and to develop a smart electricity grid. Nuclear power was more contentious: the Liberal Democrats were against it and the Conservatives in favour.

\subsection{The Coalition programme}

Although The Coalition: Our Programme for Government is 'remarkable for the range of green measures it contains - more than on any other topic', on climate change the policy commitments were almost identical with those of the outgoing Labour government (Rootes \& Carter, 2010: 996). The formation of the coalition, Rootes and Carter suggested, provided the opportunity for Cameron to cement the modernisation of the Conservative Party and to enact the green rhetoric with which he had long been identified.

The section on Energy and Climate Change stated the need to use a wide range of levers 'to cut carbon emissions, decarbonise the economy and support the creation of new green jobs and technologies'. It said that the government would 'push for the EU to demonstrate leadership in tackling international climate change, including by supporting an increase in the EU emission reduction target to $30 \%$ by 2020 '. It also announced that the government would increase the target for energy from renewable sources and 'continue public sector investment in carbon 
capture and storage (CCS) technology'; and establish a smart grid, smart meters and a full system of feed-in tariffs in electricity. And the coalition would 'create a green investment bank'. They also intended to 'establish an emissions performance standard to prevent coal-fired power stations being built unless they are equipped with sufficient carbon capture and storage to meet the emissions performance standard', and to cancel the third runway at Heathrow and refuse permissions for additional runways at Gatwick and Stansted. On the EU Emissions Trading Scheme (ETS) there was a commitment to a floor price for carbon, and to push the EU towards full auctioning of ETS permits. And through the 'Green Deal', they would encourage home energy efficiency improvements; improve energy efficiency in businesses and public sector buildings, and 'reform energy markets to deliver security of supply and investment in low carbon energy' (HM Government, 2010: 16). They would deliver an offshore electricity grid to support the development of a new generation of offshore wind power and encourage community-owned renewable energy schemes. Internationally they would 'work towards an ambitious global climate deal that will limit emissions and explore the creation of new international sources of funding for the purpose of climate change adaptation and mitigation' (HM Government, 2010: 17).

On Environment, Food and Rural Affairs, the document proposed the introduction of measures to make the import or possession of illegal timber a criminal offence; measures to protect wildlife and promote green spaces and wildlife corridors; the launch of a national tree planting campaign; increasing local accountability in the National Parks; working towards a 'zero waste' economy by encouraging recycling; creating a presumption in favour of sustainable development in the planning system (HM Government, 2010: 18).

On Transport, there was a commitment to making the transport sector 'greener and more sustainable, with tougher emission standards and support for new transport technologies'. This included 'a national recharging network for electric and plug-in hybrid vehicles' and longer rail franchises to give operators 'the incentive to invest in ... better services, better stations, longer trains and better rolling stock'. There was also a commitment to reform decision making on the prioritisation of transport projects 'so that the benefits of low carbon proposals (including light rail schemes) are fully recognised' and to the establishment of a high speed rail network 'as part of our programme of measures to fulfil our joint ambitions for creating a low carbon economy' (HM Government, 2010: 31).

Nuclear power was contentious. The Conservative manifesto committed to securing UK energy supplies by 'clearing the way for new nuclear power stations', provided that they received no public subsidy (Conservative Party, 2010: 92), whereas the Liberal Democrats promised to 'reject a new generation of nuclear power stations', because, 'based on the evidence nuclear is a far more expensive 
way of reducing carbon emissions than promoting energy conservation and renewable energy' (Liberal Democrat Party, 2010: 58). However, it was the Conservatives' position that formed the basis of the coalition nuclear policy.

\subsection{The Coalition and the Environment: promise and practice}

The appointment of Chris Huhne as Energy and Climate Change Secretary was significant as he had been a longstanding green champion. However, it is important also to look at the balance of the ministries and the rift caused by the Coalition policy on nuclear power. In addition to Huhne, the other ministers in the Department of Energy and Climate Change (DECC) were Conservatives; at the Department of Environment, Food and Rural Affairs (Defra), the all Conservative team was led by Secretary of State, Caroline Spelman, by background a lobbyist for the food and biotechnology industry. At the Department for Transport, Secretary of State Philip Hammond was flanked by two Conservative ministers and Liberal Democrat Norman Baker. Out of the twelve ministers in the relevant departments, two were Liberal Democrats.

In addition to tensions between the Conservative and Liberal democrat elements of the Coalition, there were marked tensions within the Conservative Party. Many Conservative MPs found themselves committed to positions which did not sit comfortably with their traditional beliefs and allegiances. Rootes and Carter note that:

\footnotetext{
the environment might yet prove to be a source of political discontent within the Conservative party - and therefore potentially destabilising for the coalition. Before the election, there was considerable hostility towards Cameron's green agenda within the Conservative parliamentary party and the wider grassroots membership, often expressed in vitriolic language on the party blogs. Climate change, in particular, could be a divisive issue. ... Conservative candidates in the most winnable seats ranked 'reducing Britain's carbon footprint' bottom of a list of 19 priorities for the new government, and there will be fierce resistance from many Conservatives to any measures ... that can be perceived as threatening economic recovery or imposing unnecessary costs on business. (Rootes \& Carter, 2010: 997)
}

What has the Coalition done? Briefly, on the minus side it withdrew funding for the Sustainable Development Commission (SDC) and announced that it would not carry out its proposal to make it an offence to possess illegally felled timber or bring it into the country; and it will not extend the subsidy for small-scale solar production under the Feed-In Tariff. On the plus side it halted the third runway at Heathrow and stated that it would not approve new runways at Gatwick and Stansted. A more ambiguous commitment is to HS2: as noted above, HS2's environmental credentials are disputed, there is little evidence that it will take traffic off the roads, and Friends of the Earth and other groups argue that upgrading the rail system overall would be a better use of resources. In addition, the focus on high speed rail deflected attention from the absence in the coalition agreement of 
policy on road transport and car use. Another missing item was buses, although there was talk of encouraging joint working between bus operators and local authorities (HM Government, 2010: 31), in practice 'joint working' has been a victim of expenditure cuts, with more than two-thirds of local authorities planning cuts to public transport budgets (Milmo, 2010). Nuclear power has been contentious. Although some argue that it is the only way of keeping carbon emissions down, it is not clear that the Conservatives support it because of its green credentials. As longstanding opponents of nuclear power, the disappearance of the Liberal Democrat website 'No to Nuclear Power' indicates their embarrassment, as does comment from critics such as Adrian Ramsay of the Green Party, who asked why the party overcame its opposition to nuclear power and approved the construction of eight new nuclear power stations? (Ramsay, 2010).

'Greenest ever government'? Perhaps not, but how do we judge the claim one way or another? For example, on the one hand DECC has taken steps to stimulate growth in green energy by allowing councils to sell renewable electricity generated on their land, but on the other it has been subject to budget cuts leading to the scrapping of funds or scaling down of operations to support offshore wind, biomass and geothermal energy. Again, how is cancelling the third runway at Heathrow to be measured against the abolition of the Royal Commission on Environmental Pollution or the Sustainable Development Commission? And how do promises of generating green jobs in a green economy fit the slow progress towards developing a Green Investment Bank?

When the Coalition stopped funding the Sustainable Development Commission (SDC), its independent environmental watchdog and advisory body, Jonathon Porritt (Chairman 2000-2009) responded angrily, claiming that the 'justification for getting rid of the SDC is transparently vacuous, if not downright dishonest' and 'this is an ideological decision ... driven by dogma not by evidence-based, rational analysis.' He asserted that 'the only conceivable reason for allowing dogma to dominate in this way is that the government doesn't want anyone independently auditing its performance on sustainable development - let alone a properlyresourced, indisputably expert body operating as 'a critical friend' on an inside track within government'. Secretary of State for the Environment, Caroline Spelman, argued that the matter was too important to be devolved to an outside body. Given this background, was the Coalition seriously prepared to address the issue of whether the economy was developing along inherently unsustainable lines? (Black, 2010).

The government offered four justifications for axing the SDC, the first that it would save money: the irony was that half its funding came from Defra and half from the devolved administrations and other Whitehall Departments, which all wanted to carry on working with the SDC. The second was that sustainable 
development was mainstreamed across government by being embedded in every department, the inference being that "no specialist capability at the centre is any longer required, simply because the government "gets it"". Porritt regarded this as absurd. He then observed that the SDC was a UK-wide body, and that Wales and Scotland, who have done better than Whitehall in 'mainstreaming' sustainable development, were not in favour of abolition. The only reason to which Porritt gave any credence was eliminating duplication: the SDC, because it carried out a variety of tasks, was bound to overlap with other bodies; however, it was virtually the only input ministers regularly received from the standpoint of integrated sustainable development. Further, it was the only body which worked with other public sector bodies in offering advice on sustainable development and provided independent scrutiny of government performance across the whole sustainable development agenda. The final justification was that sustainable development was too important to delegate to an external body. Here Porritt reminded us of Spelman's words, in which she cast the decision as a matter of principle and personal responsibility 'I am determined to take the lead role in driving the sustainable agenda across the whole of government, and I'm not willing to delegate this responsibility to an external body'. He commented that 'even after nine years working with dozens of government ministers, I'm astonished at such utterly brazen cynicism.' He also pointed out that the only thing Spelman had so far done as Secretary of State was to publish a new departmental strategy containing no serious reference to sustainable development. Hence his conclusion that the justification for closing the SDC was vacuous, dishonest and dogmatic. Although it was too early to make a definitive judgement about the Coalition's green agenda, the prospects were not encouraging, because "Greenest ever" has to mean something substantive. Simply smearing a sickly ideological slime over everything just won't cut it' (Porritt, 2010).

\subsection{The Green Investment Bank}

In October 2010 the Comprehensive Spending Review (CSR) was published. Many of its proposed cuts hit hard at environmental spending. Defra's budget was cut by 30 per cent (compared with a government average of 19 per cent); DECC was cut by 18 per cent; the Environment Agency lost 5,000-8,000 of 30,000 jobs; Natural England's budget was cut by 30 per cent ( 800 full-time jobs). The Review also included proposals to sell off national nature reserves, privatise parts of the Forestry Commission and sell off the Meteorological Office. The former proposals proved to be extremely unpopular and led to widespread campaigning against 'selling off our woodlands'. Rather less has been heard of the latter, but concerns have been expressed that privatisation would undermine the position of an organisation which has contributed greatly to public understanding of climate change. 
Another example of a less than full commitment to the environment was the story of the Green Investment Bank (GIB). ${ }^{2}$ The statement in the Coalition Programme that 'we will create a green investment bank' (HM Government, 2010: 16) was interesting for what it omitted: the level of funding. Everything, however, depends on this: it is the difference between tokenism and a seriously committed contribution to a green economy. The status, remit and funding of the GIB has been the subject of much political battling between ministers and departments since the formation of the coalition. The fighting was not necessarily between the coalition parties: typically it was between ministers in their ministerial roles. The CSR included a commitment to the GIB, but with a start-up figure of $£ 1$ bn against the originally anticipated $£ 2 \mathrm{bn}$; it is generally reckoned to need $£ 4-6 \mathrm{bn}$ to make any significant impact. Chris Huhne, and the climate change minister, Greg Barker, took the lead in negotiations with the Treasury supported by the Minister of State for Policy, Oliver Letwin, and the Business Secretary, Vince Cable. The Treasury continued to oppose it, proposing instead a repackaging of existing green pledges in a new fund, but Cameron promised that the GIB would be a proper bank (Murray, 2010) and Huhne openly attacked the Treasury. The matter was resolved in December 2010 with the Treasury victorious: the GIB would begin life as a fund - which would jeopardise the provision of billions of pounds of loans to green technology. Huhne conceded prioritising the deficit over the GIB, leading to the claim that he was 'forced humiliatingly into repudiating his principles, saying that sustainability must not take precedence over cutting the deficit' (Ballard, 2010). However, without Huhne's advocacy, the GIB might never have come into being at all. It was formally established in 2012, is still acting as a fund, and will have full borrowing powers from 2015 .

As suggested above, it is always difficult to push strong environmental policy during a recession, especially within a government committed to deficit reduction through cuts in public expenditure. Of course, much depends on whether the cuts are motivated by ideology or necessity. This is why Huhne's commitment to the GIB found itself so uncomfortably caught between neo-liberal ideology and the coalition's professed environmentalism. Again, although the coalition argued in its own policy documents that many environmental policies lead to green growth and employment, their commitment has in practice been weak. The result is that very few any longer seriously claim that the Coalition is the 'greenest ever government'; on the contrary, the UK seems to have reverted to 'politics as usual'?

\section{3. 'Politics as Usual'}

What is 'politics as usual'? It is the adoption of certain standard approaches to the economy, economic growth, and the protection of economic and political

\footnotetext{
${ }^{2}$ See Connelly, 2011, for a full account.
} 
interests, together with scepticism concerning the environment, especially where it is felt to be a brake on growth and profitability. This does not necessarily imply active hostility to the environment, but it does imply relative indifference. 'Politics as usual' has a structure consisting in a set of deep presuppositions, together with an associated lexical ordering between levels of presuppositions and commitments, the structuring effects of power and influence, and the limits of bureaucratic rationality. On this view, the actions of government are an expression of underlying structures of power and influence, basic beliefs and administrative stasis. Mid-way between observable action and deep presuppositions lie approaches to tactics and strategy, the manipulation and structuring of choices, and the shaping of the political opportunity structure.

An important aspect is power. Following Lukes, at the deepest level (the third dimension), there is the power of unacknowledged action-guiding presuppositions which are non-observable, unquestioned and rarely challenged. At the next level (second dimension) there is the ability to shape and manipulate agendas of public debate through reputational power, or the implicit threat arising from the belief that political actors can access other forms of power if they wish. Finally, there is explicit observable power (first dimension). Power operates on all three dimensions simultaneously, they are not mutually exclusive, they overlap, and they differ in efficiency. For instance, it is more efficient to employ reputational power to manipulate the political agenda than to rely on explicit threats or physical force; and where the political agenda is founded on deep naturalised presuppositions ensuring prior agreement on fundamental ends that is more efficient still (Lukes, 2005). ${ }^{3}$

For example, a political actor, if believed to be powerful, can rely on reputation and implicit threat to achieve success in agenda manipulation. Further, their power draws additional nourishment from the underlying set of presuppositions which absolves them of the need to argue their case explicitly because it is always already the default position. Only challengers to the status quo have to seriously argue their case whereas its defenders rarely need to provide more than a minimal level of argument. Thus defenders of the political and economic status quo possess an inbuilt advantage either because no one questions the desirability of economic growth (as an end), or of roads, planes, trade and industry (as means); or, if these are questioned, the questioning is superficial, with the challenger typically presumed to be 'sentimental' and 'unrealistic'. In this world, to be real is to be measurable, whatever is not measurable is not real, and the approved medium of measurement is GDP. In such 'debates' a conclusion is swiftly reached that

\footnotetext{
${ }^{3}$ This account is indebted to Lukes, 2005. The term 'naturalised' refers to beliefs so much taken for granted that they are believed to be the natural order of things.
} 
although hypothetical cases might exist where economic considerations are not paramount, in practice unlimited economic growth is an unqualified good. All that then remains of the policy debate is discussion of means, location or timing: when or where, rather than whether; more or less, rather than not at all; and hence opportunities for manipulation of decisions through constrained choices open up nicely.

'Politics as usual', then, concerns a set of presuppositions within which it is possible to distinguish deep presuppositions (taken for granted in all political and economic argument) from surface presuppositions which are relatively open to question. Surface presuppositions typically (but not invariably) concern means rather than ends; deep presuppositions tend to concern ends, not means. Relations between these presuppositions are governed by a lexical order with certain conditions having to be satisfied before others come into play. For 'politics as usual', once the conditions for ensuring economic growth are satisfied, environmental considerations can come into play, but not vice versa. Therefore, if environmental protection is at the expense of economic growth it should not be pursued; if it promotes economic growth it should be pursued; if it has no palpable effect on economic growth it might be pursued if desired.

Debates surrounding, for example, transport, rail, roads and aviation policy take place within this framework, where two of the presuppositions of 'politics as usual' are the desirability of economic growth and belief that the relationship between environment and economy is usually a trade-off. The second presupposition is slightly more subtle than this, in that environment and economy are not necessarily taken to clash, but where they do (and they usually will), economy should be prioritised. Both might co-exist in a green economy pursuing sustainable green development, but the implicit proviso is that this so only while there is no opposition between them. It is also worth noting that 'green growth', 'green economy' etc are typically promoted not as green qua green, but as good for the economy per se: again, environmental values are subordinated to economic values.

'Politics as usual' rests on other presuppositions too, including attitudes to the scope and limits of governmental action, taxation, property and rights,. For example, let us consider attitudes to the scope and limits of governmental action. In 2007 the political editor of the Daily Express, Macer Hall, remarked that Zac Goldsmith sought to remove the ethical dimension, which he characterised as the exercise of free choice, from daily household decisions, and claimed that 'Tories of his ilk seem to have stolen from socialism the idea that the tax system should be used to change human behaviour rather than being a necessary evil for funding essentials such as defence and policing' (Hall, 2007). Hall is right that the point of green taxation is to change behaviour and his view therefore amounts to banning green taxes on the grounds that the proper role of government does not include 
behaviour modification through taxation. This presupposition covers means, and where such presuppositions operate, certain means are regarded as impermissible irrespective of ends. ${ }^{4}$

Policy making tends to be conducted incrementally, in accordance with bounded rationality. Disjointed incrementalism is both descriptive and prescriptive. It describes both how things happen and prescribes a model for rational decision making in complex societies. In the issue attention cycle, environmental issues wax and wane in public and political consciousness; when they return to active policy consideration, they already have an institutionalised footing. They become institutionally embedded and operate within the bounds of the structural presuppositions of bureaucracies as an entrenched dimension of their policy making activity. Institutionalisation, in the form of appropriate agencies and departments, possesses the advantage of providing a ready-made structure within which policy responses can be channelled. However, this has another side, because along with inherited techniques for dealing with issues, problems tend to be defined in ways which only allow solutions in accord with prevailing political and administrative arrangements. Douglas Torgerson argues that there are limits to the 'administrative mind' (2005). This means that policy makers typically pay attention only to problems which are amenable to technological and administrative solutions. Modern 'rational' administration presupposes a vision of order and progress within which certain approaches or responses are regarded as reasonable or rational and others are not and within this frame, environmental problems are often responded to atomistically rather than holistically because to appreciate them as interconnected would constitute a challenge to our underlying views of economic development. The administrative mind cannot admit that there might be a fundamental flaw in the whole pattern of industrial development. Environmentalism mounts a challenge to the administrative mind because it implies that 'progress' may be a source of disorder, 'disrupting the natural systems upon which civilization and human life depend' (2005: 105). The administrative mind thus denigrates those who articulate a different vision. Problems cannot be admitted to be systemic crises but have to be presented in a way which presents manageable, soluble and more or less separable problems so as to match the 'functional differentiation of the administrative apparatus' (2005:106). Fragmentation of issues into different government departments leads to the overlooking of the interconnected nature of environmental problems. Doubtless there is something to be said for reframing problems to admit of practicable solutions and it would be absurd to dismiss the importance of incrementalism, bounded rationality, and the constraints of the administrative mind. But taking

\footnotetext{
${ }^{4}$ Some might regard the ends as undesirable too; thus certain means are impermissible both because they are means to improper ends, and also because they are improper means to any ends.
} 
environmentalism seriously present a serious challenge to those limits and the presuppositions which sustain them.

\subsection{Virtù and fortuna in environmental politics}

An important part of 'politics as usual' was characterised by Machiavelli as the interplay of fortuna and virtù. The relation between fortuna and virtù is the interplay between chance and abilities within the political opportunities experienced by political actors. For Machiavelli, the term virtuoso (derived from virtuे) refers to the personal qualities the prince should acquire. The interplay of virtù and fortuna is ineliminable. A virtuoso politician holding a position can achieve great things; the post is a necessary for greatness, but not sufficient; virtù, the ability to grasp what fortuna offers, is necessary too.

An example of virtù. Upon being appointed Secretary of State for Energy and Climate Change in May 2010, Chris Huhne was seen as pivotal to the success of the government's environmental policy. In the political jungle he was a 'big beast'; although the Chancellor of the Exchequer is, ex officio, one of the biggest beasts, Huhne was a sufficiently powerful virtuoso to harry the Chancellor and the Treasury in the discussions leading to the formation of the GIB. He did not fully succeed, but success is relative. He was also a forceful negotiator in international climate change negotiations. ${ }^{5}$ However, fortuna decreed that he would be forced to resign in February 2012. His successor, Edward Davey (another Liberal Democrat) is regarded as both less green and less virtuoso. Liberal Democrats generally do not lead the large and powerful departments and therefore have to be possessed of extraordinary virtù to be able to challenge the Treasury and the other powerful ministries. They have to achieve greatness rather than have greatness thrust upon them.

An example of fortuna. Before 2010, the Conservative MP Justine Greening was an eloquent opponent of a third runway at Heathrow Airport. Although her opposition might be for predominantly local reasons (her constituency lies under the flight path), her stance dovetailed with the Conservative Party's objections to Labour's plans for airport expansion. Hence the symbolism of her becoming Secretary of State for Transport in October 2010 was important; equally, her removal in September 2012 was seen as that symbolism's mirror image. Her replacement was Patrick McLoughlin, who is in favour of airport expansion. Greening's deputy at the Department for Transport, Theresa Villiers, was opposed to expansion of Heathrow and to Boris Johnson's proposal for a new airport on the Isle of Grain in the Thames estuary ('Boris Island'), and in favour both of HS2 and

${ }^{5}$ Greenpeace UK Director, John Sauven, responded to the news that Huhne would remain throughout the 2010 Cancun climate change negotiations by saying that, with 'the outcome hanging in the balance', he had a vital role to play in helping to 'broker a climate deal' (BBC News, 2010). 
freeing capacity at Heathrow through increased use of Manchester and other northern airports.

Leadership is a complex topic: key variables include power or its lack and scope of action or its lack. Powerful actors, such as the Treasury, can dominate without needing to persuade; the relatively powerless, on the other hand, can (and have to) lead through skill in negotiating or facilitating agreements, or in redefining and conceptualising the terms of debate. Transport or environment ministers are likely to be relatively powerless and hence to rely on entrepreneurial or cognitive leadership. How far they can succeed depends largely on a confluence of circumstances, although their leadership style is likely to be humdrum, not heroic or transactional, not transformational. ${ }^{6}$ In the longer term cognitive leadership can lead to significant change and to that extent 'politics as usual' can be subverted; but in the short term, the hegemony of powerful actors will tend to dominate.

When Greening left transport, it was reported that there was rejoicing in the aviation industry, while elsewhere there was condemnation and suspicion. Boris Johnson stated that 'there can be only one reason to move her - and that is to expand Heathrow' and that 'we will fight this all the way ... If we are to remain Europe's premier business hub we need a new four-runway airport, preferably to the east of London, that addresses the problem of aviation capacity before it is too late, and business is driven into the arms of our European competitors' (BBC News, 2012). Although Johnson is opposed to Heathrow expansion he is not opposed to airport expansion as such. For Goldsmith, Greening's original appointment to Transport had shown the Prime Minister's position on Heathrow to be solid and yielding so easily to pressure for her replacement indicated 'panic, not principle', while Friends of the Earth claimed that she had been 'shunted out' and was a 'victim of intense aviation lobbying over airport expansion (BBC News, 2012). Meanwhile at Defra, Spelman was replaced by Owen Paterson, a climate change sceptic largely indifferent to environmental concerns (Carrington, 2012; Monbiot 2012). Prior to this he had formulated a plan for economic growth in which the key elements were exempting micro businesses from red tape, ending energy subsidies, rapid exploitation of shale gas, and 'urgent review of airport policy to ensure Britain gets its full share of global trade' (ConservativeHome 2012). A government which was the 'greenest ever' would not have appointed him. The precise difference these personnel changes will make is unclear: but powerful environmental voices who might have challenged 'politics as usual' have lost influence. And David Cameron himself is now largely silent on the environment,

\footnotetext{
${ }^{6}$ For more on styles and types of leadership, see Wurzel \& Connelly (2011), 13.
} 
having yielded to the consolidated forces of economic orthodoxy and re-embraced 'politics as usual'.

\subsection{Airport Expansion: an ever decreasing circle}

Since 2010 chance and circumstance have combined in a move towards a third Heathrow runway. The argument, essentially, is that airport expansion was bound to happen and 'Boris Island' was essentially a decoy, whose value lay in its deflecting attention from whether expansion was desirable to where it should be. Once Boris Island is rejected, the only serious remaining option will be expansion of Heathrow. In 2012 government officials had indicated that the prospect of building a third runway at Heathrow was 'dead and buried' and that they would consider 'all ideas bar a third runway'; 'then we also had a Transport Secretary ... who lived under the flight path and had campaigned against the plan. What a difference to today, when a third runway at the UK's biggest and busiest airport is very much back on the table' (Westcott, 2013). Final decisions have yet to be taken, but it appears to be a perfect example of the reassertion of 'politics as usual', with growth to the fore, the tactic of a constrained choice between an evil and a slightly lesser evil, and some ersatz environmental concern: Boris Island would be environmentally destructive and is therefore opposed by environmental groups. Voila! Heathrow is the least worst environmental option. This political manoeuvring demonstrates the power and virtù of the Chancellor and his allies. Osborne has progressively revealed his support for more runway capacity in the south-east and for Heathrow as the only practicable solution, although still claiming that all options should be open. Read: a) all options (except not increasing capacity) are open, and although all options are 'open', some are more open than others. What is palpably absent is any systematic discussion of aviation in relation to transport or environmental policy as a whole.

We are nearing the end game. Although the government claims that its position against airport expansion remains unchanged, the appointment of the Airports Commission, under Sir Howard Davies, suggests otherwise. In November 2012, the Secretary of State for Transport, Patrick McLoughlin, announced its terms of reference (McLoughlin, 2010). It was required to report by the end of 2013 on the nature, scale and timing of the steps needed to maintain the UK's global hub status and its recommendation for actions to improve the use of existing runway capacity in the next 5 years; and to report no later than summer 2015 on options for the UK's international connectivity needs (including economic, social and environmental impact). McLoughlin remarked that 'Aviation is vital to the UK economy and we need to have a long term aviation policy which meets the challenges of the future.' The presupposition is that there will be an increase in airport capacity and debate has been reduced to the future location and expansion of aviation. Given that the next general election will be held in May 2015, the 
timescale is politically expedient, allowing the government to uphold the letter of the coalition agreement which ruled out airport expansion in the current parliament. ${ }^{7}$

The Airports Commission issued its interim report in December 2013 and recommended that London will need another runway by 2030. It shortlisted only Heathrow and Gatwick for expansion. Surprisingly, it included a proposal to extend Heathrow's existing northerly runway westwards to allow takeoffs and landings from the same runway at the same time. Patrick McLoughlin did not comment on the shortlisted options, nor guarantee that the Conservatives would support the commission's final verdict. The commission will examine the three proposals and recommend one in 2015; further studies will be made of a Thames Estuary airport (Boris Island) which might be added to the shortlist, however 'the logistical challenges are very severe'. The London Mayor's alternative of expanding Stansted, was rejected along with more than fifty other schemes (Calder, 2013a).

In an accompanying political analysis, Nigel Calder commented that 'Sir Howard Davies has tight-rope walked the line between Cameron and Boris over airport expansion', and that:

\begin{abstract}
The UK's role in global aviation has long been subservient to local politics in west and south-west London. One purpose of the Davies Commission was to elevate the debate above political squabbles. But airport expansion has become a proxy for the rivalry at the heart of the Conservative Party between the Prime Minister and the Mayor of London. Ruling out all Thames Estuary options at this stage would have fuelled that political battle rather than allowing the Airports Commission diligently to evaluate each of the three short-listed options. Sir Howard has bought some time by looking at the theoretical consequences for the environment and economic geography of an Isle of Grain development, while simultaneously focusing on his three preferred options (Calder, 2013b).
\end{abstract}

The interim report of the Airports Commission indicates the extent to which the Coalition has ceased asking serious questions about environmental policy in the round. Instead the debate has been reduced to one about timing and location mediated by factional politics within the Conservative Party.

\title{
Conclusion
}

Overall, since 2010 the Coalition government has moved decisively away from its loudly proclaimed green commitments, through a phase of relative silence, to a reassertion of traditional values. The most recent indication includes Cameron's speech discussing the need to challenge the EU's powers to dictate areas of environmental policy. He claimed that there were areas, including environmental

\footnotetext{
${ }^{7}$ Decision making on airport expansion is an example of Lukes's second dimension of power.
} 
legislation, 'where Europe has gone far too far.' He was not specific on details, but close observers think that the Conservative Party would, while continuing to accept the EU carbon emissions reduction target, oppose the setting of a separate renewables target; that they would act on Osborne's long established complaints about the 'ridiculous cost' the Habitats and Birds Directives places on UK businesses (despite a Defra investigation showing the falsity of this claim); and that they would seek to make changes to the Air Quality Directive (ENDS, 2013).

Despite appearances, 'politics as usual' never really ceased to operate. And certainly, for its advocates, 'politics as usual' is neatly in its rightful place. The Treasury reigns supreme; radical, green and powerful ministers prepared or able to challenge the Treasury have resigned or been sidelined and replaced with weaker or hostile ministers; public opinion is indifferent and believes the claims of green government to be bogus; the deep lying assumption that economic growth is paramount is triumphant. Gestures are made to green growth, sustainable development, and to the politics of ecological modernisation, but in any clash with the prevailing economic view they are put firmly in their place. 


\section{References:}

Ainsworth, P., (2009), Green Energy Bill - Power for All, Press release, 21 January 2009.

Ballard, E., (2010), 'Seven months of savage cuts leave coalition's green hue fading', (16 December 2010), New Statesman, http://www.newstatesman.com/blogs/thestaggers/2010/12/government-green-bank Retrieved at: February 1, 2011.

BBC News (2012) 'Boris Johnson's Heathrow warning after Justine Greening's move', (4 September 2012) http://www.bbc.co.uk/news/uk-politics-19475249 Retrieved at: February 10, 2013.

Beckett, A., (2008), 'What Can They be Thinking?' (26 September 2008), The Guardian.

Black, R., (2010), 'A hundred days of the 'greenest-ever' government,' BBC News, 18/8/10. http://www.bbc.co.uk/news/science-environment-10981853 Retrieved at: December 28, 2010.

Calder, N., (2013a), 'Airports Commission: New runways considered at Heathrow and Gatwick', (17 December 2013), The Independent. http://www.independent.co.uk/news/uk/home-news/airports-commission-report-thirdrunway-at-heathrow-and-second-at-gatwick-are-option--but-boris-island-left-offshortlist-9009536.html Retrieved at: January 1, 2014.

Calder, N., (2013b), 'Sir Howard Davies has tight-rope walked the line between Cameron and Boris over airport expansion', (17 December 2013), The Independent. http://www.independent.co.uk/travel/simon-calder/simon-calder-sir-howard-davies-hastightrope-walked-the-line-between-cameron-and-boris-over-airport-expansion9009695.html Retrieved at: January 1, 2014.

Cameron, D., (2006), 'The planet first, politics second', (3 September 2006), Independent on Sunday.

Cameron, D., (2008), 'The choice isn't between economy and environment', (16 June 2008), http://www.conservatives.com/tile.do?def=news.story.page\&obj_id=145279 (no longer available).

Carrington, D., (2012), 'Owen Paterson's climate change problem: cock-up or conspiracy?, (7 September 2012), The Guardian. http://www.guardian.co.uk/environment/damiancarrington-blog/2012/sep/07/owen-paterson-climate-change-sceptic Retrieved at: February 10, 2013.

Connelly, J., (2009), 'Voting Blue, Going Green? David Cameron and the Environment', M. Beech \& S. Lee (eds) The Conservatives Under David Cameron, Palgrave Macmillan, pp.134-150.

Connelly, J., (2011), 'Vote Blue, go Green, what's a bit of yellow in between?', M. Beech \& S. Lee (eds) The Cameron-Clegg Government. Palgrave Macmillan, pp.118-133.

Connelly, J., (2013), 'Coalition, Aviation and the Descent to 'Politics as Usual', L. Budd, S. Griggs \& D. Howarth (eds), Sustainable Aviation Futures, Bingley: Emerald, pp.219238.

Conservative Party, (2007), Power to the People: the Decentralised Energy Revolution. 
Conservative Party, (2009), The Low Carbon Economy: Security, Stability and Green Growth. Protecting Security: Policy Green Paper, No. 8.

Conservative Party, (2010), Invitation to Join the Government of Britain: The Conservative Manifesto 2010.

Conservative Home, (2012), 'Unemployment is down, exports are booming', (16 May 2012) http:/conservativehome.blogs.com/thetorydiary/2012/05/unemployment-is-downexports-are-booming-but-paterson-hague-and-fox-all-urge-chancellor-to-do-more.html. Retrieved at: January 1, 2014.

ENDS, (2013), 'Europe UK PM calls for roll-back of EU green laws', (24 January 2013), http://www.endseurope.com/30419/uk-pm-calls-for-rollback-of-eu-greenlaws?referrer=bulletin\&DCMP=EMC-ENDS-EUROPE-DAILY. Retrieved at February $10,2012$.

FOE, (2010), 'High Speed Rail: Upgrading existing rail network should be priority', http://www.foe.co.uk/resource/press_releases/high_speed_rail_05012011.html.

Retrieved at: December 24, 2010.

Gray, J., (1993), Beyond the New Right: Markets, Government and the Common Good, London: Routledge.

Grice, A., (2008), 'How green are the Tories?', (31 July 2008), The Independent.

Hall, M.,(2007,) 'How dare millionaire Goldsmith lecture the voters on "sacrifice', (9 December 2007), The Daily Express.

HM Government, (2010), The Coalition: Our Programme for Government.

Huhne, C., (2010), 'Chris Huhne admits green bank may be scaled back', Greenwise, http://www.greenwisebusiness.co.uk/news/chris-huhne-admits-green-bank-may-bescaled-back-2004.aspx. Retrieved at: December 17, 2010.

'Cameron's green edge' (3 September 2006), Independent on Sunday (editorial).

Liberal Democrat Party, (2010), Liberal Democrat Manifesto 2010.

Lukes, S., (2005), Power: A Radical View, second edition, Basingstoke: Palgrave Macmillan.

Lynas, M., (2008), 'World Saved ... Planet Doomed', New Statesman, 24 November 2008, $20-4$.

McLoughlin, (2012), Membership and Terms of Reference of Airports Commission. https:/www.gov.uk/government/speeches/membership-and-terms-of-reference-of-theairports-commission. Retrieved at: December 1, 2012.

Milmo, D., (2011), 'Bus services under threat from cuts', The Guardian, 3/2/11, http://www.guardian.co.uk/uk/2011/feb/03/bus-services-under-threat. Retrieved at: February 3, 2011.

Monbiot, G., (2012), 'Declaring War on the Environment', 06 September 2012, http://www.monbiot.com/2012/09/06/declaring-war-on-the-environment/. Retrieved at: February 10, 2012. 
Murray, J., (2010), 'Cameron promises Green Investment Bank will be a bank', Business Green, http://www.businessgreen.com/bg/news/1899130/cameron-promises-greeninvestment-bank-bank. Retrieved at: January 1, 2014.

Porritt, J., (2011), 'Porritt condemns 'dogmatic' decision to axe money-saving SDC', http://www.forumforthefuture.org/blog/porritt-condemns-

$\% \mathrm{E} 2 \% 80 \% 9 \mathrm{Cdogmatic} \% \mathrm{E} 2 \% 80 \% 9 \mathrm{D}$-decision-axe-money-saving-sdc. Retrieved at: January 1, 2014.

Quality of Life Policy Group, (2007), Blueprint for a Green Economy. Conservative Party.

Ramsay, A., (2010), Letter to The Guardian, (21 December 2010), http:/www.theguardian.com/politics/2010/dec/22/vince-cable-leak-in-proportion. Retrieved at: April 9, 2012

Rootes, C. \& Carter, N.,(2010), 'Take blue, add yellow, get green? The environment in the UK general election of 6 May 2010', Environmental Politics, 19: 6, pp.992-9.

Schlosberg, D. \& Rinfret, S., (2008), 'Ecological Modernisation, American Style', Environmental Politics, Vol. 17, No. 2, April 2008, pp.254-275.

Stratton, A., (2009), 'Heathrow expansion: Government survives Commons vote', (28 January 2009), The Guardian.

Summers, D., (2008), 'Delegates welcome Tory plan for high-speed rail link', (29 September 2008), The Guardian.

Westcott, R., (2013), 'Heathrow submits third runway options to Davies Commission', 17 July 2013, http://www.bbc.co.uk/news/uk-23337754. Retrieved at: July 17, 2013.

Wurzel, R. \& Connelly, J., (2011), The European Union as a Leader in International Climate Change Politics, London: Routledge. 